TARNOWSKIE STUDIA TEOLOGICZNE 34 (2015) NR 2, S. 87-114

http://dx.doi.org/ 10.15633/tst.1641

Bogumił Chmiel $^{1}$

UNIWERSYTET MARII CURIE-SKŁODOWSKIEJ W LUBLINIE

\title{
Krytyka nowożytnej postaci chrześcijaństwa zachodniego z perspektywy tradycjonalizmu integralnego
}

Celem niniejszego artykułu jest prezentacja zarzutów, które pod adresem nowożytnych form chrześcijaństwa wysunęli przedstawiciele tradycjonalizmu integralnego. Realizacja tego zamierzenia musi zostać poprzedzona kilkoma uwagami, które pozwolą właściwe zrozumieć cel i efekty pracy. Po pierwsze, należy mocno podkreślić, że tradycjonalizm integralny nie zwraca się przeciwko chrześcijaństwu in genere. W przekonaniu samych tradycjonalistów ich zarzuty, stanowiąc krytykę wyłącznie zdegenerowanych form chrześcijaństwa, są jednocześnie obroną jego prawdziwego - tradycyjnego pojmowania. $Z$ tego powodu przedstawionych argumentów nie można w żaden sposób stawiać w jednym rzędzie z poglądami myślicieli pokroju Feuerbacha, Marksa czy współczesnych „wojujących” ateistów. Po drugie, chociaż tytuł zawiera odniesienie jedynie do nowożytnego chrześcijaństwa, przedmiotem tradycjonalistycznej krytyki jest także chrześcijaństwo współczesne. Według zwolenników omawianej myśli sytuacja religijna naszych czasów jest skutkiem i kontynuacją przemian sięgających xIV wieku, przez co podział na nowożytność i współczesność, w tym akurat aspekcie, jest bezzasadny ${ }^{2}$. Po trzecie, przedmiotem analiz jest jedynie chrześcijaństwo

1 Bogumił Chmiel, absolwent teologii na Katolickim Uniwersytecie Jana Pawła II i filozofii na Uniwersytecie Marii Curie-Skłodowskiej. Doktorant na Wydziale Filozofii i Socjologii Uniwersytetu Marii Curie-Skłodowskiej w Lublinie. Przygotowuje rozprawę doktorską dotyczącą dziejów filozofii wieczystej.

2 Pomimo iż na poziomie terminologicznym tradycjonaliści akceptują powszechnie przyjmowane rozróżnienie na epokę starożytną, średniowiecze, nowożytność i współczesność, to w swojej historiozofii opierają się na "mitologicznym” pojęciu dziejów jako procesie stopniowej degeneracji opisywanej w wielu tradycjach pod postacią przejścia od „złotego wieku”, satjajugi (satya-yuga) do „wieku żelaza”, kalijugi (kali-yuga). W praktyce poszczególni tradycjonaliści różnią się we wskazaniu momentu, w którym rozpoczął się „wiek ciemny”, wszyscy 
zachodnie, a więc katolicyzm i protestantyzm. Specyfika kultury zachodniej powoduje, że to głównie pod jej adresem kierowano krytyczne uwagi ze środowiska tradycjonalistycznego. Po czwarte, poniższe rozważania opierają się głównie na poglądach trzech najwybitniejszych przedstawicieli tradycjonalizmu: Anandy K. Coomaraswamy'ego, Frithjofa Schuona oraz René Guénona. Inni myśliciele omawianego nurtu, w tym równie ważny jak wspomniani Julius Evola czy syn Anandy - Rama Coomaraswamy przytaczani są tylko na marginesie ${ }^{3}$. Po piąte wreszcie, ze względów metodologicznych główny przedmiot dociekań, a więc zarzuty formułowane pod adresem nowożytnego chrześcijaństwa, musiał zostać poprzedzony stosunkowo obszernym wprowadzeniem dotyczącym poglądów metafizycznych wyznaczających perspektywę myśli tradycjonalistycznej. Ich pominięcie uczyniłoby same zarzuty niezrozumiałymi.

\section{Perspektywa tradycjonalizmu integralnego}

Każda krytyka, niezależnie od tego, co (bądź kto) jest jej przedmiotem, dokonywana jest z określonej perspektywy. Z punktu widzenia metodologii na ową perspektywę składają się (nie zawsze wyraźnie sformułowane) twierdzenia oraz reguły dowodzenia niekwestionowane przez krytykującego i traktowane przez niego jako oczywiste. Fakt, że one same mogą stać się przedmiotem krytycznych analiz powoduje, że w rzeczywistości nie ma czegoś takiego, jak krytyka totalna - każda krytyka jest partykularna, tj. związana $\mathrm{z}$ właściwą jej perspektywą, a ważność sformułowanych uwag zależy od przyjęcia właściwego im punktu widzenia. $Z$ tego też względu przedstawienie uwag wysuwanych pod adresem nowożytnych form chrześcijaństwa zachodniego przez tradycjonalistów wymaga zarysowania twierdzeń, które - składając się na właściwą im perspektywę - decydują o takim właśnie, a nie innym profilu zarzutów.

oni jednak pozytywnie oceniają starożytność i wczesne średniowiecze (do mniej więcej XIII wieku), a renesans i dalsze epoki klasyfikują jako czas coraz głębszego upadku.

3 W przypadku włoskiego barona jego poglądy na naturę religii, a w szczególności chrześcijaństwa, znacznie różnią się od wizji pozostałych wymienionych autorów. Stąd, chociaż jest on zaliczany do elity przedstawicieli myśli tradycjonalistycznej, uwzględnienie jego poglądów wymagałoby wyjaśnień przekraczających ramy przewidziane dla artykułu. 
Przede wszystkim stanowisko tradycjonalistów trudno jednoznacznie zakwalifikować jako filozofię bądź teologię. Sami autorzy często powołują się na powstałe w XVI wieku pojęcie filozofii wieczystej (philosophia perennis), równocześnie zgłaszając zastrzeżenia do takiej terminologii, a w zasadzie jej współczesnych konotacji. Zdaniem Schuona „słowo filozofia sugeruje, słusznie lub błędnie, raczej umysłowe opracowanie niż mądrość i z tego względu nie oddaje dokładnie sensu, który zamierzamy. Religio jest tym, co «wiąże» człowieka z Niebem i angażuje jego cały byt; jeśli chodzi o termin traditio, jest on odniesiony do bardziej zewnętrznej i czasem fragmentarycznej rzeczywistości, poza tym sugeruje retrospektywne spojrzenie; nowo powstała religia "wiąże» człowieka z Niebem od momentu pierwszego objawienia, ale nie staje się «tradycją», ani nie ma «tradycji» do dwóch lub trzech pokoleń później”4. Termin „filozofia” (podobnie jak „teologia” - pojmowana jako rozumowa refleksja nad treścią wiary) jest zatem zbyt wąski - sugeruje jedynie rozumowe podejście do przedmiotu; pojęcie religii z kolei, choć oddaje specyfikę omawianej postaci wiedzy, naraża na nie mniejsze trudności. Sugeruje mianowicie, że tradycjonalizm stanowi formę nowej religii, tymczasem jest wręcz odwrotnie - tradycjonaliści ostro krytykują wszelkie próby synkretycznego tworzenia doktryn religijnych, pozostają także sceptyczni wobec nowych „objawień”. Prawda religijna, z racji jej egzystencjalnego charakteru, nie może bowiem pochodzić „z dołu” - od człowieka, być jego wytworem, konstruktem rozumu „Z naszej strony absolutnie odmawiamy nadania tej nazwy [tradycji - przyp. B. Ch.] czemukolwiek, co jest czysto ludzkiego porządku [...]. Filozofia, nawet będąc wszystkim tym, czym powinna być, nie ma prawa do tego określenia, gdyż należy w zupełności do porządku racjonalnego, nawet jeśli nie zaprzecza temu wszystkiemu, co wykracza poza ten porządek. Nie jest niczym więcej, niż strukturą wzniesioną przez ludzkie indywidua bez jakiegokolwiek objawienia czy inspiracji, co znaczy, skracając, że jest zasadniczo "profańska»" . Tradycjonalizm nie jest zatem ani rozumowym dociekaniem nad doktryną religijną, ani samą religią. Jest raczej her-

4 F. Schuon, Religio perennis, [w:] Crossing religious frontiers, ed. H. Oldmeadow, Bloomington 2010, s. 13 (Studies in Comparative Religion) (wszystkie tłumaczenia z języka angielskiego pochodzą ode mnie).

R. Guénon, The crisis of the modern world, transl. M. Pallis, A. Osborne, R. C. Nicholson, Hillsdale 2001, s. 29. 
meneutyczną refleksją nad treścią poszczególnych systemów religijnych/ kulturowych podejmowaną celem wydobycia wspólnego im wszystkim uniwersalnego duchowego rdzenia („Tradycji”); umożliwiając tym samym duchowe odrodzenie jednostek i całej kultury ${ }^{6}$.

Aby zrozumieć czym jest ów „rdzeń” poszukiwany przez tradycjonalistów, trzeba omówić poszczególne elementy zaproponowanej charakterystyki. Przede wszystkim myśl omawianych autorów (określana przez nich samych jako „metafizyka”, „nauka sakralna”, „filozofia wieczysta”) ma postać „hermetycznej" egzegezy tekstów oraz innych form kultury wyrażających istotne treści. Hermetyczność tradycjonalistycznej interpretacji polega zasadniczo na tym, że intencją autorów nie jest filologiczne (hermeneutyczne) odczytanie tekstu (dzieła sztuki, elementu kultury), a więc wierne oddanie jego rozumienia w kulturze, w której powstał i funkcjonował, ale wskazanie jednego, uniwersalnego sensu duchowego, odwiecznie ukrytego za wielością sformułowań poszczególnych doktryn religijnych, filozoficznych i zjawisk kulturowych ${ }^{7}$. Cały wysiłek tradycjonalistów opiera się na przekonaniu, że: „wszystkie formy, wszystkie symbole, wszystkie dogmaty, poprzez swoją negację błędu i afirmację Prawdy, umożliwiają podążanie za światłem Objawienia, które nie jest niczym innym, jak światłem Intelektu zwróconego ku jego boskiemu Źródłu”" . W ten sposób tradycjonaliści, w swoim mniemaniu, nie proponują nowej doktryny, a jedynie - opierając się na specyficznej egzegezie skupionej na symbolicznym znaczeniu poszczególnych

\footnotetext{
6 „Istnieją dwie komplementarne funkcje właściwe dla tradycyjnych nauk: $\mathrm{z}$ jednej strony, jako aplikacje doktryny, umożliwiają połączenie różnych porządków rzeczywistości i zintegrowanie ich w jedność indywidualnej syntezy, a z drugiej, konstytuują - przynajmniej dla niektórych i zgodnie z ich indywidualnymi możliwościami - przygotowanie do wyższej wiedzy oraz sposób jej osiągnięcia [...]”" (tamże, s. 51).

7 Przedmiotem niniejszego artykułu nie jest geneza takiej „hermetycznej” hermeneutyki, można jednak wspomnieć (celem nakreślenia szerszego kontekstu), że podobne pojmowanie filozofii stało się bardzo popularne w epoce renesansu, a zwłaszcza po roku 1463, w którym to Marcelo Ficino przetłumaczył Corpus Hermeticum - zbiór dialogów przypisywany mitycznemu Hermesowi Trismegistosowi, który (wraz z innymi mitycznymi postaciami - prisci theologi) został uznany za przekaźnika prawdy ukrytej w starożytnych tekstach. Celem interpretacji było odkrycie owej najgłębszej prawdy, w czym pomagała (na zasadzie inspiracji oraz konkretnych wskazówek) kabała rozwijana przez takie postacie, jak: Pico della Mirandola, Johanes Reuchlin czy Cornelius Agrippa. Por. N. Goodrick-Clarke, The Western esoteric tradition. A historical introduction, Oxford 2008, s. 50.

8 F. Schuon, The transcendent unity of religions, Wheaton 2005, s. XxxIV.
} 
elementów kultury - waloryzują poszczególne tradycje religijne, ukazując ich zasadniczą jedność 9 .

Jedność poszukiwana przez tradycjonalitów nie ma charakteru doktryny, którą można by „wyłuskać” z poszczególnych systemów religijnych i kultur, ale zasadza się na wspólnych im wszystkim strukturach symbolicznych, wyrażających boską prawdę i umożliwiających osiągnięcie zbawienia. Poszczególne elementy składające się na religię (święte teksty, mity, postacie założycieli, obrzędy, formuły doktrynalne, zasady moralne i ascetyczne) i funkcjonujące w koherentnej z nimi kulturze (stratyfikacja społeczna, funkcje poszczególnych stanów, narracje wyjaśniające genezę wspólnot) potraktowane jako indywidua różnią się od siebie i zdają się wzajemnie wykluczać. Umieszczone jednak w całościowym układzie wzajemnych odniesień i potraktowane na sposób symboliczny (jako odnoszące się, a zarazem zawierające w sobie wyższą rzeczywistość) wykazują daleko idące podobieństwo ${ }^{10}$. Przy takim punkcie widzenia istotowa jedność religii pełni rolę swoistego założenia, które kieruje refleksją, a jednocześnie znajduje $\mathrm{w}$ niej swoje potwierdzenie ${ }^{11}$.

${ }^{9} \mathrm{~W}$ tym aspekcie tradycjonalizm integralny jest współczesną próbą realizacji hasła Mikołaja z Kuzy „istnieje tylko jedna religia w wielości rytów” (tenże, On peaceful unity of faith (De pace fidei), [w:] J. Hopkins, Nicolas of Cusa's De pace fidei and Cribatio Alkorani: translation and analysis, Minneapolis 2004, s. 635). Zasadnicza różnica polegałaby w tym przypadku na tym, że Kuzańczyk próbuje tworzyć jedną uniwersalną religię, która okazuje się być w swej istocie chrześcijaństwem, tradycjonaliści zaś, inspirowani myślą Orientu, zdecydowanie odżegnują się od takich projektów.

${ }^{10}$ Jeśli za główny cel tradycjonalistów będziemy uważać „ukazanie wspólnego metafizycznego fundamentu wszystkich religii i tego, że różnorodne kultury są fundamentalnie odniesione jednak do drugiej jako będące dialektami jednego duchowego i intelektualnego języka [...]", to owymi „dialektami” są struktury symboliczne poszczególnych kultur, a metajęzykiem twierdzenia samych tradycjonalistów. Cyt. za A. K. Coomaraswamy, On the pertinence of philosophy, [w:] The essential Ananda K. Coomaraswamy, ed. R. P. Coomaraswamy, Bloomington 2004, s. 72. Taka perspektywa badawcza była bliska nie tylko tradycjonalistom, ale także szerokiemu gronu badaczy, do których zaliczyć można M. Eliadego, J. Campbella, których praca opierała się na założeniu wedle którego „,dzięki symbolom świat staje się "przeźroczysty», zdolny do «ukazywania» transcendencji” (M. Eliade, Sacrum, mit, historia, przeł. A. Tatarkiewicz, Warszawa 1974, s. 134).

${ }^{11}$ „W celu uchwycenia religijnego punktu widzenia istotne jest dostrzeżenie jedności, poprzez którą jej wszystkie konstytutywne elementy są w sposób konieczny powiązane; ta jedność jest jednością duchowego punktu widzenia, będącego zalążkiem konkretnego Objawienia” (F. Schuon, The transcendent unity of religions, dz. cyt., s. 107). 
Powyższa uwaga może się spotkać z zarzutem błędu petitio principii, jednak jego wysunięcie zakłada już pewne presupozycje wynikające $\mathrm{z}$ traktowania tradycjonalizmu jako filozofii na modłę zachodnią, a więc refleksji rozumowej. Tymczasem omawiana myśl jest „filozofią” w takim samym sensie, w jakim określa się tym terminem systemy hinduistyczne (darśana) lub buddyzm. Celem tradycjonalizmu nie jest formułowanie ciągów, opartych na empirii, racjonalnych argumentów, ale odsłonięcie duchowej jedności kryjącej się za pluralizmem przejawów religijnych i kulturowych „[f]ilozofia pierwsza, [...] uznając za oczywistą zasadę «tak na górze, jak na dole» i vice versa, jest w stanie znaleźć w każdym mikrokosmicznym fakcie ślad lub symbol makrokosmicznej rzeczywistości, i zgodnie z tym uciec się do «dowodu» poprzez analogię; ta pozornie dedukcyjna procedura jest tutaj zaangażowana na sposób demonstracji, a nie na sposób dowodu tam, gdzie logiczny dowód jest poza dyskusją, a jego miejsce jest zajęte bądź przez wiarę (Augustyńskie credo ut inteligam) bądź przez oczywistość bezpośredniego doświadczenia (alaukikapratyaksa)"12. Tym samym myśl tradycjonalizmu zakłada duchowe nastawienie odbiorcy daleko wykraczające poza to, co można określić mianem „uczciwości intelektualnej”. Ten duchowy impuls tradycjonalizm chce scharakteryzować, rozbudzić i ukierunkować w obrębie tej tradycji religijnej, w której odbiorca funkcjonuje.

Tradycjonaliści nie są zatem orędownikami supremacji jednej religii czy kultury, ale zwolennikami fundamentalnej (ezoterycznej) jedności wszystkich „tradycyjnych” doktryn i kultur. Podejmując próbę scharakteryzowania zasady owej jedności, należy zacząć od stwierdzenia, że ostatecznie nie daje się ona ująć w żadną definicję - „czysta i absolutna Prawda może być znaleziona jedynie poza jej wszystkimi możliwymi ekspresjami; te ekspresje jako takie nie mogą rościć sobie właściwości samej Prawdy; ich względna odległość od niej przejawia się poprzez ich zróżnicowanie i wielość, poprzez które są ściśle ograniczone”"13. Owymi „ekspresjami” są poszczególne religie i kultury będące próbą wyrażenia tego, co Nieskończone, w skończonej formie dogmatów, rytów i form kultury ${ }^{14}$. Tym samym wszystkie

12 A. K. Coomaraswamy, On the pertinence of philosophy, dz. cyt., s. 71.

${ }_{13}$ F. Schuon, The transcendent unity of religions, dz. cyt., s. 20.

${ }^{14}$ „Każda religia jest z konieczności adaptacją, a adaptacja implikuje ograniczenie [...]. Te ograniczenia muszą być widoczne, w taki lub inny sposób, w powstawaniu form religijnych i jest nieuchronne, że powinny się manifestować wraz z biegiem rozwoju tychże form, stając 
doktryny są identyczne w niewyrażalnej istocie, a różnicują się w formach, $\mathrm{w}$ jakich owa istota jest wyrażana ${ }^{15}$. Każda religia jest zatem zrelatywizowaną do danego miejsca i czasu manifestacją absolutnej i ponadczasowej Prawdy; we właściwej sobie "przestrzeni” może być określana jako prawdziwa, ale tylko w sensie względnym - prawdziwa w danej kulturze i dla danej społeczności. Pozostając we właściwych sobie ramach symbolicznych, konkretna religia ma odpowiednią „moc zbawczą” pozwalającą jej wyznawcom osiągnąć transcendentny cel. W momencie, w którym konkretny system rości sobie prawo do wyłączności i absolutności zostaje popełniony błąd ograniczona i skończona forma zostaje wzięta za samą treść, której jest tylko przejawem.

Niemożliwość wyrażenia uniwersalnej Prawdy leżącej u źródeł każdej religii nie oznacza, że jest ona niepoznawalna, oznacza jedynie, że treść takiego aktu poznawczego nie daje się wyczerpująco zamknąć w dogmatycznych formułach. Zdaniem tradycjonalistów najwyższą formą wiedzy, do której ma doprowadzić religia (a szerzej - cała kultura) ma charakter intuicyjnego oglądu. Waga, jaką omawiani autorzy przywiązują do natury poznania bezpośredniego oraz rola tej formy wiedzy w krytyce zachodnich form religijnych, wymaga, aby dokładniej przyjrzeć się rozumieniu pojęcia intuicji.

Przede wszystkim „intuicja intelektualna, poprzez którą wyłącznie wiedza metafizyczna jest osiągana, nie ma absolutnie nic wspólnego z tymi innymi «intuicjami», o których mówią pewni współcześni filozofowie: ta druga odnosi się do rzeczywistości zmysłowej i jest w rzeczywistości pod-racjonalna, podczas gdy wcześniejsza, będąca czystą inteligencją, jest - wprost przeciwnie - ponad-racjonalna"16. Intuicja odnosi się bezpośrednio do boskiej Rzeczywistości, którą ujmuje w sposób niezapośredniczony i niedyskursywny. Tym samym, jako wiedza wyższego rzędu, nie może ona podlegać ocenie niższych władz poznawczych (rozumu, danych empirycznych), od których

się najbardziej widocznymi pod koniec ich cyklu, do którego z konieczności się przyczyniają" (tamże, s. 104).

${ }^{15}$ „Prawdziwie tradycjonalistyczna perspektywa jest zawsze i wszędzie zasadniczo taka sama, niezależnie od tego, jaką zewnętrzną postać może przyjąć, różnorodne formy, odpowiednio dopasowane do zróżnicowanych warunków umysłowych i różnorodnych okoliczności czasu i miejsca, są jedynie przejawami jednej i tej samej prawdy [...]” (R. Guénon, The crisis of the modern world, dz. cyt., s. 30).

16 Tamże, s. 41. 
jest niezależna i które przekracza ${ }^{17}$. Poznanie intuicyjne nie jest więc kolejną formą poznania, ale specyficzną dyspozycją podmiotu, wynikającą z jego wyjątkowego statusu ontologicznego. Niezależność od rozumu i zmysłów, a więc tego, co indywidualizuje akt poznawczy poprzez umiejscowienie go w czasie i przestrzeni, powoduje, że intuicja wykracza nie tylko poza wiedzę naukową, ale i poza samą wiarę religijną (teologię), która zatrzymuje się na poziomie historycznych przejawów Prawdy. Religia może jedynie doprowadzić do tego oglądu (i to jest jej celem), ale nigdy go nie zastąpi.

Absolutna niezależność intuicji od czynników empirycznych znajduje swój wyraz w tezie, wedle której „w przypadku intuicji intelektualnej wiedza nie jest posiadana przez jednostkę $w$ takiej mierze, w jakiej jest ona indywidualnością, ale o tyle, o ile w swej najgłębszej istocie jest ona nieodróżniona od swej boskiej Zasady. Z tego względu metafizyczna pewność jest absolutna na mocy identyczności pomiędzy poznającym i poznawanym w Intelekcie"18. Teza o jedności podmiotu i przedmiotu ma fundamentalne znaczenie i musi być właściwie zrozumiana. Zasadniczym błędem byłoby pojmowanie przytoczonego twierdzenia jedynie w sensie epistemologicznym - jako pewnego stanu poznawczego, który podmiot osiąga na pewnym etapie praktyk religijnych. W rzeczywistości ów stan zniesienia zróżnicowania na podmiot i przedmiot ma charakter rozpoznania faktycznego stanu rzeczy, będącego tym samym wyzwoleniem jednostki ze złudzenia, w którym pozostawała. Mamy tutaj zatem nie tylko tezę epistemologiczną, ale i ontologiczną. W swej najgłębszej istocie człowiek jest tożsamy z ponad-osobową Boskością, jest jednym z jej przejawów, zaś zbawienie nie jest niczym innym, jak uświadomieniem owej jedności. Ostatecznym celem wszystkich religii jest wyprowadzenie ludzi ze stanu niewiedzy poprzez uświadomienie człowiekowi jego autentycznej natury. Owo uświadomienie, będące w rzeczy samej istotą intuicji, jest „reintegracją człowieka w Boskości, przypadkowego w Absolucie, skończonego w Nieskończonym”"19.

17 Por. tamże, s. 52.

${ }^{18}$ F. Schuon, The transcendent unity of religions, dz. cyt., s. xxx. Guénon wyraża tę prawdę następująco: ,jedyna prawdziwa wiedza to taka, która implikuje identyfikację podmiotu z przedmiotem, lub - jeśli ktoś preferuje rozważenie tej relacji w odwrotnym porządku - asymilację przedmiotu przez podmiot” (tenże, [w:] The essential René Guénon. Metaphysic, tradition and the crisis of modernity, ed. J. Herlihy, Bloomington 2009, s. 128).

19 F. Schuon, The transcendent unity of religions, dz. cyt., s. 51. 
Wyrwanie człowieka ze stanu głębokiej metafizycznej niewiedzy jest źródłem (twórcami religii są ci, którzy dostrzegli Prawdę), istotą (cały kult, rytuały, dogmaty i moralność mają wyrażać jej naturę) oraz celem wszystkich autentycznych doktryn religijnych. Jedność tego doświadczenia gwarantuje transcendentną jedność wszystkich religii, a jego ostateczna niewysławialność jest źródłem ich wielości. Próbując opisać sam proces wyzwolenia, należy wskazać na następujące elementy: po pierwsze, tożsamość podmiotu i Absolutu jest pewnym faktem, który nie tyle ma być ukonstytuowany przez aktywność podmiotu, ile rozpoznany. Cała symbolika religijna i kulturowa ma umożliwić i ukierunkować ten wysiłek - pomóc człowiekowi uświadomić sobie własną naturę, a więc pewien stan faktyczny, co do którego podmiot pozostawał w niewiedzy ${ }^{20}$. Po drugie, skoro źródłem poznania nie jest rozum, ale przekraczająca ludzką kondycję intuicja, to warunki do jej rozwinięcia zaktualizowania tkwiącego w podmiocie potencjału - mają charakter nie tyle intelektualny, ile duchowo-kulturowy. W aspekcie rozwoju duchowego istotną rolę odgrywa moralność, która „z pewnością nie gwarantuje metafizycznej wiedzy, ale jest warunkiem integralnego funkcjonowania podmiotu na fundamencie adekwatnych przesłanek doktrynalnych"21. Z drugiej strony, do zdobycia samowiedzy sama moralność nie wystarcza, konieczny jest łańcuch tradycji, a więc ciąg autentycznych przekazicieli symbolicznych środków (mitów, doktryn, rytów inicjacji), za pomocą których można osiągnąć poznanie (tradycjonaliści ów „rdzeń” określają mianem „Tradycji Pierwotnej”). Po trzecie „,metafizyka traktuje Najwyższą Identyczność jako nierozdzielną jedność potencjalności i aktu, ciemności i światła, utrzymując, że mogą one i muszą być rozważane oddzielnie, kiedy próbujemy zrozumieć

${ }^{20}$ „Punktem wyjściowym metafizycznych wyrażeń jest zawsze nade wszystko coś intuicyjnie oczywistego lub pewnego, co jest komunikowane tym, którzy są w stanie to odebrać poprzez symboliczne lub dialektyczne środki przewidziane do obudzenia w nich ukrytej wiedzy, którą noszą nieświadomie - a nawet można by rzec - wiecznie, w sobie" (tamże, s. xxxiI). Idea ta ma w przypadku tradycjonalistów pochodzenie orientalne, gdzie złudzenie (mayā) jest przeszkodą, a zarazem źródłem cierpienia, którą poznanie prawdziwe (pramāna) ma usunąć. W przypadku myśli zachodniej najbliższa jej jest myśl Platona z jego ideą prawdy (aletheia) jako przypomnienia, odkrycia rzeczywistej natury bytu.

${ }^{21}$ Tamże, s. 152. Wymagania moralne, o których mówią tradycjonaliści, są postulowane na tej samej zasadzie, na której punktem wyjścia jogi jest praktyka zasad moralnych (yama). Moralność nie jest tu celem samym w sobie - autonomiczną wartością, której realizacja daje nadzieję na zbawienie. Jest jedynie jednym z elementów umożliwiających poznanie. 
ich działanie w tożsamości w Tym lub w Nim”22. Najwyższa Identyczność, o której mówi Coomaraswamy, oznacza zarazem ponadosobowy Absolut wzięty sam w sobie, ale również Absolut jako immanentną zasadę świata, a więc $\mathrm{w}$ jego wielorakich manifestacjach ${ }^{23}$. Jedną $\mathrm{z}$ tych manifestacji jest człowiek, którego celem jest powrót do świadomości owej jedności. Celem człowieka, jak już wspomniano, jest uświadomienie sobie tej podstawowej jedności, a skoro do jej istoty należy zniesienie wszelkich opozycji (światło ciemność, dobro - zło, nakaz - wolność, działanie - spoczynek, piękno szpetota), to droga, którą musi przebyć podmiot, polega na wyzbyciu się wszystkiego tego, co indywidualizuje jednostkę, czyni ją odrębną od reszty świata. Tym samym filozofia tradycjonalizmu, wbrew wszystkim nowożytnym nurtom psychologicznym, „nie jest «poszukiwaniem jaźni», ale ukazaniem nierzeczywistości wszystkich tych «dusz», «jaźni» $\mathrm{i}$ «Ja» zwyczajowo rozumianych. Nie możemy w rzeczywistości wiedzieć, kim jesteśmy, ale możemy stać się tym, kim jesteśmy, poprzez poznanie, kim nie jesteśmy; tym, czym jesteśmy, jest immanentny Bóg, a On sam nie może wiedzieć, czym jest, ponieważ, nie jest żadnym czymś, ani nigdy czymś się nie staje. Nasz kres zostanie osiągnięty, kiedy nie będziemy już więcej żadnym kims'” ${ }^{24}$. To zatracenie własnego „ja” jest w rzeczywistości pozbyciem się

${ }^{22}$ A. K. Coomaraswamy, On the pertinence of philosophy, dz. cyt., s. $72 . \mathrm{W}$ innym miejscu Coomaraswamy tak określą tę fundamentalną tezę: „Główny punkt, jaki winien być uświadomiony, jest taki, że jeśli w rzeczywistości Jego natura transcenduje wszystkie logiczne antytezy, to nie może On być znaleziony takim, jaki jest sam w sobie przez poszukiwacza, który bierze pod uwagę tylko Jego byt, to znaczy, jego «Przód» lub «Światło», ale tylko przez Obserwatora, który dostrzega Jego «Tył» lub «Ciemność». Jest On nie tylko Miłością i Życiem, ale także Trwogą i Śmiercią, wszechobecną (vyāpaka) i nieprzejawioną (alinga) Osobą (puruṣa), "poprzez poznanie której człowiek jest wyzwolony i osiąga wieczność (amrtatvam)” (A. K. Coomaraswamy, Mahā Puruṣa, [w:] Coomaraswamy, 2: Selected papers. Metaphysic, ed. R. Lipsey, Princeton 1977, s. 384).

${ }^{23} \mathrm{Na}$ gruncie myśli indyjskiej można powiedzieć, że w pierwszym przypadku mówimy o stanie nieprzejawionym Absolutu (avyakta), a w drugim o przejawionym (vyakta). W pierwszym przypadku Absolut jest sam w sobie, w drugim manifestuje się częściowo w świecie.

${ }^{24}$ A. K. Coomaraswamy, Traditional psychology, [w:] Coomaraswamy, 2: Selected papers. Metaphysic, dz. cyt., s. 373-374. Trudno w tym miejscu rozwijać analizy poszczególnych wątków, warto jednak zaznaczyć, że formalnie w poglądach tradycjonalistów można dopatrywać się idei Hegla a rebours. Punktem stycznym jest pojmowanie natury religii oraz część wniosków, jakie z tego wypływają. „Człowiek wychodzi w niej [w religii - przyp. B. Ch.] poza swą czystą subiektywność, jednostkowość, odczuwanie potrzeb, granicę, a duch ujmuje w nim samego siebie - istotny duch staje się w nim obecny dla istotnego ducha. Człowiek dystansu- 
jaźni pozornej, empirycznej - wytworzonej w wyniku kontaktu ze światem i w gruncie rzeczy szkodliwej. Tym samym źródłem i celem wszelkiej religii jest wyzbycie się siebie (obumarcia fałszywego „ja”) i odrodzenie autentycznego, "przebóstwionego" podmiotu pozbawionego partykularnych cech wynikających z przylgnięcia do świata ${ }^{25}$.

\section{Krytyka nowożytnych form chrześcijaństwa}

Powyższe rozważania pozwoliły zarysować punkt widzenia, z którego zwolennicy tradycjonalizmu krytykują nowożytny sposób rozumienia religii. Zanim jednak zostanie on przedstawiony trzeba poczynić jeszcze jedną uwagę. W dotychczasowych analizach, wszędzie gdzie to było możliwe, starałem się umieszczać obok siebie pojęcia religii i kultury. Jest to konieczne, gdyż dla tradycjonalistów przestrzenią, która ma objawiać człowiekowi jego samego, wskazać cel, ku któremu winien zmierzać oraz dostarczyć środków do jego osiągnięcia, jest cała kultura, a nie tylko religia. Stratyfikacja społeczna wraz z przypisanymi do określonych stanów obowiązkami, architektura, sztuka, porządek etapów życia, narracje mitologiczne, cykliczne obrzędy - wszystkie te elementy, nawet gdy nie są bezpośrednio związane z religią, mają „karmić” ducha - ukazywać mu jego źródło, naturę oraz cel, a także dostarczyć narzędzi potrzebnych do uzyskania pełnej samowiedzy. Ogromna część pracy tradycjonalistów sprowadza się do odczytywania owych symbolicznych struktur i wykazywania paraleli między kulturami i religiami. Z tego względu religia jest tylko częścią większej soteriologicznej struktury. Jest to uzasadnione tym, że ostatecznie cały wszechświat jest częściową manifestacją Boskości, a co za tym idzie, zbawcze poznanie jest

je się w niej od swoich ograniczonych, czasowych celów, od potrzeb i rozkoszy teraźniejszości, a istota istnieje w sposób wolny u siebie - wewnętrzny Bóg jest tożsamy z zewnętrznym. Dlatego religia nie powinna być niczym subiektywnym, należącym do podmiotu jako takiego, ale winna być czymś wyzbytym jego szczegółowości jako czysto myślowa, czysto ogólna wiedza" (G. W. F. Hegel, Encyklopedia nauk filozoficznych, przeł. Ś. F. Nowicki, Warszawa 1990, s. 49).

${ }^{25}$ "Celem wszystkich religii jest oderwanie człowieka - jego umysłu, mowy i ciała - od przyjemności zmysłowych i prowadzenie go w kierunku Pana. Wielcy ludzie pojawiali się od czasu do czasu, ustanawiając religie celem uwolnienia ludzi od przywiązania do zmysłów, gdyż to nasze zmysły skłaniają nas do grzechu" (Jagadguru Sri Chandrasekharendra Saraswati Swamigal, On religion, [w:] Crossing religious frontiers, dz. cyt., s. 30). 
ostatecznie samopoznaniem owego ponad-osobowego Absolutu ${ }^{26}$. Z tego też względu zarzuty, które tradycjonaliści kierują pod adresem religii, są częścią bardziej ogólnej krytyki kultury nowożytnej.

Wszyscy tradycjonaliści zgadzają się, że współczesna epoka jest stanem głębokiej degeneracji kultury i religii. Opisując ten stan, odwołują się do pojęcia kalijugi, wieku żelaza, wieku ciemnego - wszystkie te pojęcia oznaczają nie tylko moralny upadek epoki, ale przede wszystkim najgłębszą duchową i kulturową dezorganizację, której upadek obyczajów jest tylko przejawem. Opisując współczesną kulturę, Guénon wskazuje następującą analogię między nią a czasami dekadencji klasycznego hellenizmu: „czysto «profańska» filozofia zyskała popularność: pojawienie się sceptycyzmu z jednej strony, a stoickiego i epikurejskiego moralizmu z drugiej, wystarczają, aby pokazać, do jakiego stopnia umysłowość zanikła. W tym samym czasie starożytne święte doktryny, ledwo co rozumiane przez kogokolwiek, zdegenerowały się, poprzez ów brak zrozumienia, w "poganizm» w prawdziwym sensie tego słowa, to znaczy stały się niczym więcej, jak "przesądami» - rzeczami, które - straciwszy swoje głębsze znacznie - przetrwały dla siebie samych jedynie jako zewnętrzne manifestacje”27. Istotą upadku jest zatem zatracenie głębszego rozumienia kultury - człowiek, nie będąc w stanie odkryć symbolicznej struktury, przed którą staje, zatrzymuje się jedynie na jej zewnętrznych, zmysłowych przejawach jako na ostatecznej rzeczywistości. Miejsce fundamentalnego sensu zostaje zastąpione sensem pozornym - „nasza śmiertelna część może przetrwać «samym chlebem», ale to poprzez Mit nasz Wewnętrzny Człowiek jest karmiony, lub - jeśli zastąpimy prawdziwe mity propagandowymi mitami «rasy», "podniesienia poziomu moralnego», "postępu» i «misji cywilizacyjnej» - Wewnętrzny Człowiek głoduje”28. Powyższych uwag nie należy rozumieć jedynie w wąskim sensie zaniku sztuki religijnej bądź zaniku „metafizycznych” dzieł. Już samo rozbicie kultury na porządek sakralny i profański jest oznaką upadku. W społeczeństwach

${ }^{26}$ Twierdzenie to prowadzi do pytania o źródło takiego stanu rzeczy, a więc o przyczynę, dla której Absolut musiał się zamanifestować, aby poprzez ludzkość osiągnąć samowiedzę. Ananda Coomaraswamy jest skłonny przyjąć, że jest to jakaś forma samozbawienia Absolutu przejście od jedności nieuświadomionej i nieprzejawionej, przez pluralizm przejawów i stopniowe uświadomienie do jedności nad-świadomiej (tj. różnej od normalnych form wiedzy).

${ }^{27}$ R. Guénon, The crisis of the modern world, dz. cyt., s. 14.

${ }_{28}$ A. K. Coomaraswamy, The bugbear of literacy, [w:] The essential Ananda K. Coomaraswa$m y$, dz. cyt., s. 60 . 
tradycyjnych, a więc takich, które wcielały ideały bliskie tradycjonalistom, powyższe oddzielenie nie funkcjonowało - wszystkie instytucje, ryty i zasady były ponadludzkie - stanowiły wyraz świętych wartości i wzorców, które w nich się koncentrowały, przez co pojmowano je jako „mocniej” istniejące niż czasowa i zmienna rzeczywistość. Ten transcendentny charakter przejawiał się najmocniej w ich ahistorycznym postrzeganiu - miały być odwieczne oraz sankcjonowane boskim autorytetem.

Zasadniczym znamieniem dekadencji i upadku nie jest zatem wrogość czy walka $\mathrm{z}$ religią, ale zawężenie perspektywy myślenia współczesnego człowieka - „głównym znamieniem naszych czasów nie jest to, że życie zmierza do wyczerpania się niemal wyłącznie na płaszczyźnie samsarycznej, lecz to, że nasza cywilizacja pobudza i wychwala tego typu życie, uznając je nie tyle za stan faktyczny, ile raczej za coś wartościowego, coś, co powinno nastać, coś słusznego" 29 .

Degenerację kultury można dostrzec we wszystkich jej przejawach. W przypadku sztuki jej klasycznym (tradycyjnym) celem „nie było zabawienie nas, ale dosłownie "przypomnienie». Śpiew nie jest dla zadowolenia uszu, ani obraz dla satysfakcji oczu (chociaż te zmysły mogą być wyuczone do uznawania piękna prawdy i można im ufać, gdy zostały już wyćwiczone), ale dla uzyskania efektu takiej transformacji naszego bytu, jak w przypadku wszystkich czynności rytualnych. Oznacza to w rzeczy samej, że sztuki rytuału są najbardziej «artystyczne», ponieważ są najbardziej «poprawne», jako że takie muszą być, aby przynosić efekt”30. Istotą działalności artystycznej było przebóstwienie człowieka, ukazanie mu jego natury - tych najgłębszych pokładów bytu, które artysta wyrażał swoimi dziełami, a odbiorca mógł odkryć („zrozumieć”), kontemplując symbolikę dzieła ${ }^{31}$. Tymczasem sztuka nowożytna, zamiast wyrażać we właściwej sobie formie boski porządek i umożliwiać jego realizację w indywidualnym życiu, stała się

${ }^{29}$ J. Evola, Ariya wciąż czuwa na Sẹpim Szczycie, [w:] tegoż, Na antypodach modernizmu. Pisma wybrane, red. M. Rostkowski, Biała Podlaska 2014, s. 38.

${ }^{30}$ A. K. Coomaraswamy, A figure of speech, or a figure of thought, [w:] The essential Ananda K. Coomaraswamy, dz. cyt., s. 31 .

${ }^{31}$ Przejawem takiej tradycyjnej funkcji sztuki było przekonanie artystów, że ich twórczość inspiruje i kieruje jakaś wyższa istota, a oni sami są jedynie jej narzędziami. Innym przykładem, na który powołuje się Coomarasawamy, jest idea katharsis - sztuka miała oczyścić człowieka, wyzwolić w nim boskość, oderwać go od jego ziemskiego bytowania. Współcześnie ma jedynie szokować, wyrażać uczucia lub je wywoływać. 
sentymentalną ekspresją konkretnego, historycznego „ja” artysty, przez co, zamiast prowadzić do wyzwolenia, jeszcze bardziej wikła człowieka w jego przypadkowym bycie.

Na płaszczyźnie poznawczej ograniczony punkt widzenia przejawia się w metodologicznym naturalizmie współczesnego człowieka - „bez względu na specyficzny rodzaj rozważań, którym człowiek się oddaje, zawsze ma na myśli jeden cel: wyjaśnienie zjawisk naturalnych. Zaczynając od takiego ograniczonego punktu widzenia, jest on nieuchronnie prowadzony do założenia, wedle którego każdy możliwy rodzaj wiedzy jest po prostu mniej lub bardziej niedoskonałą próbą dojścia do wyjaśnienia zjawisk przyrodniczych" ${ }^{32}$. W przypadku aktywności poznawczej, analogicznie jak w sferze sztuki, istotą upadku nie jest zanik tego typu działalności (w obu przypadkach mamy raczej do czynienia z eksplozją aktywności), ale zatracenie jej najgłębszego sensu. Tak jak sztuka miała stanowić środek zarówno ekspresji, jak i zrozumienia boskości tkwiącej w człowieku, tak i poznanie miało prowadzić do mądrości, a więc umiejętności życia opartej na rozpoznaniu ostatecznej natury bytu ${ }^{33}$. W przypadku nauki nowożytnej wszelkie rzetelne poznanie zostało ograniczone do wiedzy empirycznej. Nie chodzi tutaj jedynie o dyrektywy metodologiczne właściwe naukom empirycznym, ale o swoisty model wiedzy funkcjonujący w kulturze - „wydaje się, że dla nowoczesnych ludzi nie istnieje nic innego poza tym, co może być zobaczone lub dotknięte, lub, co najwyżej - jeśli nawet przyznają oni teoretycznie, że coś innego może istnieć - spieszą określić to nie tylko jako nieznane, ale jako «niepoznawalne»" ${ }^{34}$. Myślenie współczesnego człowieka jest zamknięte w materialnym świecie nie na mocy decyzji, ale swoistego „kodu kulturowego", który za wzór realności stawia świat fizyczny, za wzór racjonalności argumentację nauk empirycznych, a za ideał szczęścia hedonizm doznań

${ }^{32}$ R. Guénon, The great triad, trans. P. Kinsley, Cambrige 1991, s. 135-136.

${ }_{33}$ Sapiencjalny, a zarazem soteriologiczny, charakter poznania jest wyjątkowo mocno podkreślany przez wszystkich tradycjonalistów. W ten sposób ich filozofia stanowi nie tylko nawiązanie do myśli orientalnej, w której takie pojmowanie filozofii jest czymś oczywistym, ale także do klasycznej myśli greckiej i chrześcijańskiej: „Pierwotnym znaczeniem słowa sophia, «mądrość» jest «umiejętność», tak jak w sanskrycie kausalam oznacza «umiejętność» jakiegokolwiek rodzaju, zarówno w tworzeniu, wytwarzaniu i wiedzy" (A. K. Coomaraswamy, A figure of speech, or a figure of thought, dz. cyt., s. 23).

${ }_{34}$ R. Guénon, A material civilization, [w:] The betrayal of tradition. Essays on the spiritual crisis of modernity, ed. H. Oldmeadow, Bloomington 2005, s. 17. 
zmysłowych ${ }^{35}$. Podobnie jak w przypadku sztuki, nauka zatrzymuje się na zewnętrznych przejawach świata, już nawet nie negując, ale pomijając jego głębszy aspekt. Ograniczenie myślenia do sfery tego, co zmienne, płynne i skończone bez domniemania tego, co - jako wieczne i niezmienne - istnieje „poza” światem fenomenów i poprzez niego się jedynie przejawia, prowadzi do relatywizmu i sceptycyzmu naszej epoki. Porównując kulturę do okularów, można pokusić się o stwierdzenie, że według tradycjonalistów nowożytna kultura zachodnia oślepiła człowieka - „widzi” on tylko to, co zewnętrzne, zmienne, ulotne i pozorne, a nie dostrzega absolutnej istoty rzeczy.

Totalna krytyka nowoczesnej kultury znajduje także swoje oparcie w kwestiach społecznych. W opinii tradycjonalistów jednym z zasadniczych elementów tradycyjnych społeczeństw był system stanowy, który - podobnie jak pozostałe formy kultury - stanowił jednocześnie przejaw i drogę do realizacji boskiego ładu. Istotą tradycyjnej stratyfikacji społecznej był porządek hierarchiczny, na czele którego stał władca uosabiający nadprzyrodzoną moc - „świat tradycyjny znał boską królewskość. Znał most między dwoma światami tj. inicjację; znał dwie drogi do tego, co transcendentne, a mianowicie heroiczne działanie i kontemplację; znał pośrednictwo, tj. rytuały i wierność; znał społeczny fundament czyli tradycyjne prawo i system kastowy; znał również ziemski symbol polityczny, tj. imperium" ${ }^{36}$. Podział społeczności na stany nie był, w opinii omawianych autorów, jedynie faktem społecznym, lecz miał istotne znaczenie metafizyczne. Przynależność do danej kasty definiowała jednostkę, wyznaczała jej miejsce w świecie, a jednocześnie - na mocy obowiązków i praw przypisanych tejże pozycji wskazywała drogę samorealizacji ${ }^{37}$. Człowiek pojmował siebie samego, świat

35 „Nowoczesny człowiek, bez względu na to, jak głębokie mogą być jego «materialistyczne» czy «duchowe» przekonania, dzięki swoim praktycznym i bezpośrednim doświadczeniom rozwija rozumienie rzeczywistości tylko w odniesieniu do świata ciał fizycznych i zawsze pod wpływem bezpośrednich i bieżących doświadczeń. Oto prawdziwy materializm, o który oskarżyć należy naszych współczesnych. Wszystkie inne - formułowane w terminach naukowych lub filozoficznych - wersje materializmu, są jedynie zjawiskami drugorzędnymi” (J. Evola, Doktryna dwóch natur, [w:] tegoż, Na antypodach modernizmu. Pisma wybrane, dz. cyt., s. 27).

${ }^{36}$ Tamże, s. 30.

37 Ilustracją takiego pojmowania porządku społecznego jest dialog Ardżuny z Kryszną opisany w Bhagawadgicie. Inkarnacja Wisznu rozwiewa wątpliwości wojownika, wyjaśniając mu, że obowiązek walki wynika z jego pozycji społecznej (varna), która stanowi podstawę porządku moralnego. Działanie zgodne z obowiązkami przypisanymi danej kaście (karma-margā) jest jedną z dróg osiągnięcia wyzwolenia: „Lepszy jest własny obowiązek [spełniany] nawet 
i Boga właśnie w kategoriach stanów oraz przynależnych im praw i obowiązków (łaciński ethos, indyjska dharma). Nowożytny egalitaryzm sprawił, że: „nikt już dłużej nie zajmuje miejsca, które powinien normalnie zajmować na mocy swej własnej natury; to właśnie oznacza stwierdzenie, że kasty już nie istnieją, gdyż kasta - w tradycyjnym znaczeniu - nie jest niczym innym niż indywidualną naturą, z całym szeregiem zdolności, które się z nią wiążą i które predysponują każdego człowieka do wypełniania takiej czy innej konkretnej funkcji" ${ }^{38}$. Zanik społeczeństwa kastowego, pojmowany powszechnie jako błogosławieństwo i wyzwolenie człowieka, stał się jego przekleństwem. Człowiek pozbawiony trwałej pozycji społecznej stracił metafizyczną orientację - jego działania przestały być realizacją obiektywnego ładu, którego jednostka jest częścią, a stały się chaotycznym poszukiwaniem sposobu wyrażenia i troski o własne (konkretne, historyczne) ,ja”. W ślad za tym zanikł sakralny charakter pracy i obowiązku. Zdaniem Coomaraswamy’ego „W normalnych społeczeństwach konieczne trudy produkcji i budowy nie są zwykłą «robotą», ale także rytuałami, zaś związane z nimi poezja i muzyka są swoistą liturgią. "Mniejsze misteria» rzemiosła były naturalnym przygotowaniem dla większych "misteriów królestwa niebieskiego" " ${ }^{39}$. Praca przestała być drogą zbawienia, stając się jedynie środkiem utrzymania lub narzędziem zaspokajania potrzeb konkretnej empirycznej jaźni. W ten sposób praca zatraciła jakikolwiek metafizyczny sens, a mówienie o „powołaniu” w odniesieniu do obowiązków dnia codziennego stało się anachronizmem ${ }^{40}$.

Powyższe zjawiska są jedynie najważniejszymi znamionami kryzysu, który przenika całą kulturę nowożytną. Inne jego przejawy można śledzić w każdym wymiarze ludzkiego bytowania (praca, masowa edukacja, rozrywka, władza). Wszystkie można jednak sprowadzić do jednego, fundamentalnego wymiaru - ludzkie istnienie zostało zamknięte w materialnej doczesności i zwierzęcości, a cała kultura, zamiast wyrywać ludzi z tego nienaturalnego stanu, zaślepia człowieka, tłumiąc jego wrodzony impuls transcendencji ${ }^{41}$. Źródłem takiej totalnej degeneracji jest, zdaniem tradycjonali-

bez powodzenia od dobrze spełnionego cudzego obowiązku" (Bhagawadgita, przeł. J. Sachse, Wrocław 1988, III, 35).

${ }^{38}$ R. Guénon, The crisis of the modern world, dz. cyt., 69.

${ }^{39}$ A. K. Coomaraswamy, The bugbear of literacy, dz. cyt., s. 61.

${ }^{40}$ Por. M. Eliade, Sacrum, mit, historia, dz. cyt., s. 107.

${ }^{41}$ Taki pogląd współgra $\mathrm{z}$ przekonaniem o soteriologicznej funkcji poznania. Zasadnicza różnica między wartościową kulturą tradycyjną a zdegenerowaną nowożytną opiera się 
stów, rozwijający się od końca średniowiecza humanizm, którego istotą jest „zredukowanie wszystkiego do czysto ludzkich proporcji, wyeliminowanie każdej zasady wyższego porządku oraz, można tak to określić, symboliczny odwrót od Nieba pod pretekstem zdobycia Ziemi [...]. Humanizm był pierwszą formą tego, co potem stało się współczesnym sekularyzmem; następnie - ze względu na pragnienie zredukowania wszystkiego do ludzkiej miary jako celu samego w sobie - nowoczesna cywilizacja pogarszała się faza po fazie aż osiągnęła etap najniższych elementów w człowieku, dążąc do zaspokojenia prawie wyłącznie potrzeb związanych z materialną stroną jego istoty [...]" ${ }^{42}$. Istotą upadku Zachodu jest postawienie w centrum człowieka, pojętego jednak nie jako wzór (natura), którą należy zrealizować, ale jako konkretna historyczna jednostka, której potrzeby, wyobrażenia i przeżycia stają się źródłem, celem i zasadą funkcjonowania całej kultury. Taki zdegenerowany humanizm jest tożsamy $\mathrm{z}$ indywidualizmem, pojętym jako „negacja jakiejkolwiek zasady wyższej niż jednostkowość i konsekwentna redukcja cywilizacji, we wszystkich jej aspektach, do czysto ludzkich elementów [...]"43.

Odnosząc powyższe uwagi bezpośrednio do kwestii religijnych, trzeba mieć na uwadze, że główne teksty, na które będziemy się powoływać, powstały przed zmianami zapoczątkowanymi przez II Sobór Watykański. Biorąc pod uwagę zarówno istotę tradycjonalizmu, jak i losy jego przedstawicieli, trudno przypuszczać, aby podzielali oni entuzjazm, z jakim zmiany posoborowe zostały przyjęte w całym zachodnim świecie. Stąd poniższe uwagi odnoszą się do tego, co można określić mianem „tradycyjnego” katolicyzmu, a więc tego nurtu, który pozostaje krytyczny wobec zmian ostatnich sześćdziesięciu lat.

Wszyscy omawiani autorzy pozostawali zgodni co do zasadniczej tezy o wyjątkowej roli Kościoła katolickiego - „to wyłącznie w katolicyzmie jest przechowywane wszystko to, co postało na Zachodzie z ducha tradycyjnego [...]"44. Powody, dla których katolicyzm zachowuje w oczach tradycjonalistów uprzywilejowaną rolę, można wywnioskować na podstawie krytyki, jaką

na funkcji, jaką pełni. Pierwsza przypomina o potencjale najgłębszej istoty człowieczeństwa i dostarcza środków do jego realizacji, druga zagłusza wrodzone (naturalne) dążenia, wyczerpując ich energię na poziomie doczesnego, zmysłowego (hedonistycznego) bytowania.

${ }^{42} \mathrm{R}$. Guénon, The crisis of the modern world, dz. cyt., s. 17.

43 Tamże, s. 55.

44 Tamże, s. 63. 
Guénon kieruje pod adresem protestantyzmu. Omawiając epokę renesansu, stwierdza on, że: „w tych czasach tradycja Zachodu przybrała zewnętrznie specyficzną religijną formę, będąc w rzeczywistości reprezentowana przez katolicyzm; dlatego to w perspektywie religijnej powinniśmy szukać rewolucji [skierowanej] przeciwko tradycyjnemu światopoglądowi, rewolucji, która - gdy uzyskała określoną formę - stała się znana jako protestantyzm. Nietrudno dostrzec, że jest to manifestacja indywidualizmu; w rzeczy samej można to określić jako indywidualizm odniesiony do religii. Protestantyzm, tak jak nowoczesny świat, jest zbudowany wyłącznie na negacji, tej samej negacji zasad, która jest istotą indywidualizmu" ${ }^{45}$. Istota protestantyzmu jest zatem tożsama $\mathrm{z}$ esencją nowoczesnego, leżącego na antypodach tradycjonalizmu, myślenia, które swoim humanizmem i indywidualizmem doprowadziło do degeneracji kultury zachodniej. Istotą indywidualizmu jest skupienie uwagi na konkretnym, historycznym człowieku - jego potrzebach, mniemaniach i dążeniach - jako ostatecznym wyznaczniku wartości dla całej kultury; takim skupieniem na religijnych pragnieniach jednostki jest właśnie reformacja. Liczy się tylko to, co jednostka, jako konkretna indywidualność „doświadcza” tu i teraz w kontakcie z tekstem Pisma Świętego. W odniesieniu do społecznego wymiaru życia religijnego oznaczało to odrzucenie absolutnych roszczeń jakichkolwiek instytucji oraz idący z tym w parze egalitaryzm - nikt nie jest uprzywilejowany na mocy urzędu do wcielania i reprezentowania wyższego porządku; każdy jest równy wobec Boga i żadna instytucja nie może pośredniczyć między Stwórcą a stworzeniem.

Podczas gdy w katolicyzmie Kościół posiada boskie prerogatywy „protestantyzm, odmówił autorytetu organizacji powołanej do prawowitej interpretacji religijnej tradycji Zachodu, a w to miejsce domagał się postawienia "wolnego krytycyzmu», to znaczy dowolnej interpretacji wynikającej z osobistego osądu [...]"46. W Kościele katolickim między jednostką a Bogiem stoi nadprzyrodzony autorytet Kościoła pojętego nie jako zespół ludzi, ale jako działający w historii, a jednocześnie ponadhistoryczny twór bosko-ludzki - forma obecności Boga w świecie. Do hierarchicznego Kościoła należy interpretacja Objawienia, udzielanie sakramentów i władza duszpasterska. Tak jak w innych tradycyjnych społecznościach katolik staje

\footnotetext{
45 Tamże, s. 60.

${ }^{46}$ Tamże, s. 61.
} 
wobec Boga w Kościele, tj. w tym konkretnym miejscu, które wyznacza jego ziemskie powołanie, a w perspektywie ostatecznej - drogę zbawienia. Zasadą interpretacji owego „miejsca” nie jest jednak on sam, ale Kościół oraz sam porządek funkcjonujący pod postacią stanu. Protestantyzm, odrzucając autorytet Kościoła, postawił człowieka „twarzą w twarz” z Bogiem (do takiej tezy daje się sprowadzić zasadę sola Scriptura - skoro Bóg jest obecny w swoim w Piśmie Świętym, to człowiek, czytając Pismo, staje wobec Boga i nie potrzebuje żadnego wsparcia ze strony instytucji). Okazało się jednak, że takie odniesienie bardzo łatwo prowadzi do tego, o czym wiedział już Ksenofanes - człowiek pozbawiony aktywnego autorytetu, który byłby zarówno ziemski, jak i boski, tworzy sobie obraz Boga na swoje podobieństwo - dopasowuje obraz Absolutu do swoich indywidualnych preferencji, potrzeb i lęków. Posłuszeństwo wiary w ramach wyznaczonych przez nadprzyrodzony autorytet Kościoła ulegało stopniowej degeneracji, przeradzając się w protestantyzmie w „wymyślanie” Boga, czego dobitnym świadectwem jest liczba sekt poreformacyjnych.

Rozkład chrześcijaństwa, będący w istocie jednym z przejawów ogólnego upadku kultury Zachodu, przejawia się także w innych formach. Jedną z nich jest sentymentalizm i moralizm współczesnej religii. Zdaniem Guénona: „Z powodu racjonalizmu, religia musiała utonąć w sentymentalizmie, a w krajach anglosaskich można znaleźć najbardziej uderzające przykłady tego zjawiska. To, co zostało, nie jest już nawet kurczącą się i zdeformowaną religią, ale zwykłym «zdewoceniem», to znaczy, mętnymi i uczuciowymi pragnieniami nieopartymi na żadnej realnej wiedzy" ${ }^{47}$. Analizując przytoczony cytat, należy podkreślić, że krytyka kierowana pod adresem współczesnych form religijnych nie odwołuje się do braku empirycznego ugruntowania, co mógłby sugerować zwrot „nieoparte na żadnej realnej wiedzy”. Istotą zarzutu jest właśnie to, że skoro współczesna mentalność pojmuje wiedzę jedynie na sposób empiryczny i pragmatyczny (czego świadectwem jest konieczność powyższego zastrzeżenia, wskazująca, jak głęboko zakorzeniły się w nas idee pozytywizmu), to jedyną funkcją wiary religijnej pozostaje zaspokajanie potrzeb „uczuciowych”. W ten sposób religia odrywa się od swojego źródła i zasady - przestaje przypominać człowiekowi, że jego obecna kondycja jest nieadekwatna do jego istoty (a więc w pewnym sensie wytwarzać i wzmacniać poczucie dyskomfortu wynikające z takiego właśnie

47 Tamże. 
„ziemskiego” bytowania), na rzecz „komfortu psychicznego”, „spełnienia własnej osobowości”, „samorealizacji”. Oczywiście wszystkie te pojęcia mogą być pojmowane zgodnie $z$ tradycyjnym (i tradycjonalistycznym) rozumieniem, wtedy jednak nie oznaczają doznań psychicznych/duchowych, ale pewien stan ontologiczny. Stanowi temu, będącemu efektem długiego procesu transformacji dokonanego mocą środków zapewnianych przez ryty religijne, mogą, ale - jak pokazują świadectwa świętych - wcale nie muszą, towarzyszyć pozytywne doznania psychiczne/duchowe ${ }^{48}$.

W parze z sentymentalizmem idzie moralizm, który w gruncie rzeczy jest bliźniaczym względem niego efektem racjonalizmu. W perspektywie myśli nowożytnej coraz bardziej dochodzi do głosu przekonanie, wedle którego, skoro dziedzina wartości nie może być zrozumiana w sposób naukowy, to jako autonomiczna sfera działania „moralnego” musi należeć do sfery uczuć „moralnych”, która to sfera - jako niepodlegająca władzy empirii i rozumu - już została przekazana we władanie religii i sztuce. Podobnie jak w przypadku sentymentalizmu, oparcie pojęcia „racjonalności” na wzorcu nauk empirycznych doprowadziło do pozbawienia działania (moralnego, estetycznego) teoretycznej podbudowy, co z kolei doprowadziło do zaliczenia sztuki i moralności do sfery irracjonalnej. Podczas gdy zazwyczaj powyższy proces wiąże się z postaciami empirystów brytyjskich, to zdaniem Guénona geneza tego procesu sięga czasów reformacji - „protestancki moralizm, stopniowo eliminując cały fundament doktrynalny, skończył się degeneracją w to, co określa się «świecką moralnością», która zalicza do swoich zwolenników reprezentantów wszystkich rodzajów «liberalnego protestantyzmu», jak również otwartych wrogów wszystkich idei religijnych [...]" ${ }^{49}$. Moralność oderwana w kulturze protestanckiej od całego kontekstu metafizycznego (przejawiającego się w hierarchii społecznej, prerogatywach instytucji kościelnych i państwowych stanowiących manifestację kosmicznego ładu) stała się dziedziną subiektywnych (emocjonalnych) mniemań religijnych lub sferą pragmatycznej „umowy społecznej”. W obu przypadkach moralność została wykorzeniona $z$ właściwego jej „środowiska” i siłą rzeczy uległa degeneracji. Nacisk kładziony ma kodeks moralny (protestancki purytanizm) maskuje tylko wynaturzoną istotę moralności, podobnie jak egzaltowane

${ }^{48}$ Jest raczej odwrotnie, dla wielu świętych życie doczesne zaczyna być męką wynikającą $\mathrm{z}$ oddalenia od Boga.

49 R. Guénon, The crisis of the modern world, dz. cyt., s. 61-62. 
kazania ukrywają pustkę duchową. Istotą tego wynaturzenia jest zaś fakt, że w nowożytnym pojmowaniu moralność nie służy niczemu poza i ponad sobą samą - bycie „dobrym człowiekiem” stało się celem samym w sobie w takiej samej mierze, w jakiej poczucie „powiewu” Ducha Świętego lub wzruszenia towarzyszące kazaniom stały się celem uczestnictwa w nabożeństwach ${ }^{50}$. Podczas gdy w religiach tradycyjnych moralność jest jedynie początkowym etapem $\mathrm{w}$ procesie inicjacji - przygotowaniem do bardziej zaawansowanych poziomów - to dla nowożytnych chrześcijan stała się ona, obok sentymentalnych wzruszeń, istotą religii. „Pokój [duchowy] i dobro [moralne]", zamiast pozostać środkiem, stały się istotą i celem praktyk religijnych.

Pojęcia antropocentryzmu, humanizmu i indywidualizmu oznaczają w zasadzie to samo zjawisko polegające na ześrodkowaniu kultury na historycznej jednostce i jej potrzebach i skutkujące w sferze religijnej subiektywizmem, sentymentalizmem i moralizmem. Wszystkie te trzy znamiona wynikają z zatrzymania się na tym, co empiryczne, a więc powierzchowne, zmienne i relatywne. Efektem zawężenia perspektywy jest niemożność dostrzeżenia głębszego (ezoterycznego) sensu kultury i religii - „gdzie można znaleźć, nawet w katolicyzmie, ludzi, którzy znają głębsze znaczenie doktryny, jaką wyznają zewnętrznie, i kto, nienależący do "wiernych» w mniej lub bardziej sztuczny sposób, i to bardziej poprzez sentyment niż intelekt, «zna» prawdę tradycji, o której utrzymują, że jest ich. Chcielibyśmy zobaczyć dowód, że istnieje przynajmniej kilku takich ludzi, gdyż byłaby to największa i zapewne jedyna nadzieja zbawienia dla Zachodu; musimy jednak przyznać, że do tej pory nie zliczyliśmy ani jednego [...]"'11. Skutkiem braku dostępu do autentycznej Tradycji przekazywanej poprzez tradycyjne religie jest stan permanentnego sporu między „wiernymi”, gdyż „tam, gdzie nie istnieje już nic innego, jak tylko zewnętrzne formy, które nie odzwierciedlają żadnego głębszego porządku, nie może być nic innego, jak tylko różnice w odniesieniu do innych cywilizacji. Nie jest możliwe żadne porozumienie, tak długo jak nie ma żadnych pryncypiów,

${ }^{50}$ Banalnym wręcz świadectwem tego zjawiska jest popularność twierdzenia, że wszystkie religie są tak samo wartościowe, gdyż wszystkie sankcjonują moralnie dobre życie. Taki argument skrywa oczywiście założenie, że celem religii jest uczynienie ludzi moralnie dobrymi.

${ }^{51}$ The essential René Guénon. Metaphysic, Tradition and the Crisis of Modernity, dz. cyt., s. 41. 
i to $\mathrm{z}$ tego powodu aktualny brak umocowania $\mathrm{w}$ tradycji wydaje się nam najgłębszym korzeniem zachodniej dewiacji" ${ }^{52}$. Nie znając uniwersalnej istoty religii ani symbolicznej natury dziejowych postaci, w jakich się ona przejawia, ludzie "religijni” kłócą się o zewnętrzne formy, zapominając o prawdziwym wrogu, jakim jest zdegenerowana kultura niszcząca sam rdzeń myślenia tradycyjnego. Trudno jednak mówić na temat możliwości „przypomnienia” o autentycznej naturze religii, skoro resztki tego, co było zachodnim chrześcijaństwem, przesiąknięte ideałami humanizmu, stały się wrogiem człowieka, utwierdzającym go (może w nieco bardziej subtelny sposób) w jego egotyzmie. W gruncie rzeczy „nie może istnieć nic poza antagonizmem pomiędzy duchem religijnym, w prawdziwym sensie tego słowa, i nowożytną mentalnością, a każdy kompromis wiąże się z osłabieniem pierwszego, a wzmocnieniem drugiej, której wrogość nie może być w ten sposób złagodzona, gdyż może ona celować wyłącznie w całkowitą destrukcję wszystkiego, co w ludzkości odzwierciedla wyższą niż ludzka rzeczywistość" ${ }^{3}$. Triumfem myślenia nowoczesnego jest zawężenie perspektywy w taki sposób, że człowiek współczesny, choćby i religijny, cały czas pozostaje „na powierzchni” religii (na jej poziomie egzoteryczym), myśląc, że problemy, które napotyka, idee, o które walczy, i „wartości”, które realizuje, należą do jej istoty. Taka redukcja sfery religijnej jest tylko przejawem ogólnej dekadencji kultury wynikającej z jej antropocentryzmu i skutkującej próbami uczynienia religii bardziej „ludzką”. Im bardziej jednak ludzka staje się religia (i kultura), tym mniej jest ona boska.

Ostatnim elementem, na który warto zwrócić uwagę w kontekście degeneracji zachodnich form chrześcijaństwa, jest synkretyzm religijny. Silny wpływ myśli orientalnej mógłby sugerować, że tradycjonaliści będą zwolennikami przenoszenia na grunt europejski idei hinduistycznych, buddyjskich i islamskich. Sięgające epoki renesansu próby stworzenia jednej uniwersalnej religii, z jedną doktryną, moralnością i organizacją, a różniącej się jedynie formami kultu, są jednak stanowczo odrzucane przez tradycjonalistów. Bezcelowość takich zabiegów wynika z przynajmniej dwóch powodów. Po pierwsze jedyną odpowiednią tradycją dla kultury Zachodu jest chrześcijaństwo (katolicyzm) „,nie dlatego, że nie istnieje żadne inne

${ }^{52}$ R. Guénon, Not fusion but mutual understanding, [w:] Crossing religious frontier, dz. cyt., S. 41.

53 Tenże, The crisis of the modern world, dz. cyt., s. 95. 
wcielenie prawdy, ale z tego względu, że mentalność Zachodu jest do niego przystosowana i wymaga religii tego właśnie rodzaju"54. Jak już zostało to ukazane, zbawczą funkcję pełni nie sama religia, ale cała kultura, w której doktryna, kult i moralność religijna stanowią jedynie część. Ta „część” jest (powinna być) najmocniej „nasycona” odniesieniami do Absolutu, ale to nie oznacza, że można ją wyizolować z całego kulturowego kontekstu. Chrześcijaństwo „pasuje” do kultury Zachodu i tylko ono może jej przynieść wyzwolenie, o ile wcześniej samo odnajdzie swoją istotę. Cały wysiłek tradycjonalistów w odniesieniu do kultury zachodniej sprowadza się tym samym nie do zastąpienia jej ideami orientalnymi, ale do uświadomienia owej najgłębszej istoty, która w mistycznym oglądzie okazuje się tożsama z odnośnym doświadczeniem Orientu - „część z najbardziej wpływowych obrońców dogmatów chrześcijańskich można znaleźć wśród ludzi Wschodu, którzy sami nie są chrześcijanami, a nawet nigdy chcieli nimi zostać, ale rozpoznają w Tradycji chrześcijańskiej wcielenie uniwersalnej prawdy, której Bóg nigdy i nigdzie nie zostawił bez świadka" 55 .

Drugi powód, chociaż pozostaje związany z pierwszym, ma odmienny ciężar gatunkowy. $\mathrm{O}$ ile nieadekwatność innych systemów religijnych w odniesieniu do kultury Zachodu powoduje, że tradycjonaliści odrzucają wszelkie próby przeszczepiania ich na grunt europejski, o tyle próba stworzenia „nowej” religii jest jeszcze bardziej bezcelowa. Wszelkie takie projekty są szkodliwe, gdyż - najogólniej mówiąc - w obecnym klimacie duchowym są one skazane na subiektywizm wynikający $\mathrm{z}$ antropocentryzmu. Dekadencja czasów, w których żyjemy, dotknęła między innymi naszej sfery duchowej - „otępiła” ją, przez co trudniej nam ujmować Prawdę. Nie jest to niemożliwe, jednak zawsze będzie częściowe, ograniczone i podatne na skażenie błędem. Bezpieczną drogą jest zwrot ku tradycji i jej autorytetom - „religia dostarcza oficjalnej interpretacji - przez świętych lub mędrców. Hindusi mają to, co jest określane jako smyrti, jak również pisma takich osób, jak Adi Śankara, nie mówiąc już o guru Kanchi, który jest jego żyjącym spadkobiercą. Muzułmanie mają komentarze do Koranu, takie jak te Ibn Arabiego i Al-Ghazalego. Żydzi mają Haftorę, jak również swoich rabinów upoważnionych do dawania aktualnej interpretacji. Chrześcijanie

${ }^{54}$ A. K. Coomarasawamy, Eastern wisdom and Western knowledgle, [w:] The essential Ananda K. Coomaraswamy, dz. cyt., s. 90.

55 Tamże, s. 95. 
mają ojców Kościoła, doktorów oraz to, co jest określane jako «Magisterium Nauczycielskie». A tym, co we wszystkich tych żywych źródłach wyznacza autentyczność, jest fakt, że ich nauczanie w żaden sposób nie odbiega od nauczania ich poprzedników, a ostatecznie nie odbiega od autentycznego Objawienia"56. W obliczu totalnej degeneracji kultury rozwiązaniem jest nie próba wytworzenia nowej doktryny, ale zwrot ku już istniejącym tradycjom. Ostatecznie bowiem do odwiecznej Tradycji należy nie tylko zbiór tych struktur symbolicznych, które odsyłają do Boskości, ale również sam proces ich przekazywania, będący zarazem gwarantem autentyczności poszczególnych „strumieni” Objawienia ${ }^{57}$.

Powyższe dociekania można, tytułem podsumowania, odnieść do idei kosmicznego ładu, która może stanowić dobrą perspektywę dla holistycznego streszczenia powyższych analiz. Dla zachowania klarowności posłużę się koncepcją grecką, ale warto zaznaczyć, że analogiczne wnioski można uzasadnić na gruncie idei indyjskich, częściowo egipskich, perskich, być może mezopotamskich. Dla Greków rzeczywistość przyrodnicza i społeczna tworzy obiektywny ład - kosmos. Religia, moralność, nauka i sztuka są jedynie częściami tegoż ładu, przez co ich autonomia jest jedynie względna - normy i kanony właściwe poszczególnym sferom bytu i ludzkiej aktywności są jedynie przejawami jednego uniwersalnego prawa. Teoretycznym odzwierciedleniem takiego pojmowania świata jest zasada, wedle której byt, dobro i piękno stanowią transcendentalia, a więc uniwersalne aspekty rzeczy istniejących. Tym samym o każdej rzeczy można orzekać w kategoriach poznawczych, moralnych oraz estetycznych - są to różne aspekty myślenia, odpowiadające różnym aspektom bytu oraz ludzkiej natury. Żadna z tych sfer nie jest jednak wyłączona z porządku „racjonalności”, a więc dziedziny rozumnej refleksji nad bytem. Ostatecznie taki porządek jest możliwy dlatego, że człowiek sam jest częścią kosmosu, jego racjonalność (logos), jest przejawem uniwersalnej racjonalności świata. Działanie racjonalne, jako

${ }^{56}$ R. P. Coomaraswamy, Ancient beliefs or modern superstitions: the search for authenticity, [w:] The betrayal of tradition. Essays on the spiritual crisis of modernity, dz. cyt., s. 64-65.

57 „Święci we wszystkich czasach cierpieli z powodu przywar pewnych kapłanów; ale - będąc daleko od odrzucenia tradycji z tego powodu - poprzez swoją własną świętość kompensowali to wszystko, czego brakowało w ówczesnym kapłaństwie. Jedyny środek «reformowania» religii polega na reformowaniu samego siebie. Jest niezbędne, aby uchwycić fakt, że obrzędy niosą dużo większą wartość niż osobista cnota" (F. Schuon, No activity without truth, [w:] The betrayal of tradition. Essays on the spiritual crisis of modernity, dz. cyt., s. 9). 
działanie zgodne z odczytanym porządkiem kosmicznym (z naturą), jest zarazem piękne, dobre i „zbawcze” - prowadzi do spełnienia ludzkiego bytu. Przy takiej perspektywie pierwszym znamieniem upadku jest oddzielenie tych trzech porządków i zredukowanie racjonalności do sfery poznawczej, a pozostawienie piękna i dobra w sztucznie wypreparowanej sferze uczuć estetycznych i moralnych ${ }^{58}$. Racjonalność ogranicza się do zorientowanego empirycznie rozumu, a piękno i dobro grzęzną w sentymentalizmie i moralizmie.

Ze strony tradycjonalistów rozwinięciu powyższych idei w duchu orientalnym towarzyszyło wyeksponowanie boskiego charakteru kosmicznego porządku (świat i człowiek jako przejawy ponadosobowej boskości) oraz „dodanie” antropologii, w myśl której człowiek, aby rozpoznać, a zarazem zrealizować swoje autentyczne (nieempiryczne, boskie) „ja”, musiał, paradoksalnie, porzucić swoje subiektywne mniemania i pragnienia (sferę „ja” fałszywego, empirycznego) na drodze odkrycia i spełnienia obiektywnych wymagań wynikających z zajmowania takiego, a nie innego miejsca w kosmosie ${ }^{59}$. Tymczasem w myśleniu humanistycznym jednostka nie jest odtwórcą obiektywnego ładu, ale - zgodnie z deklaracją, jaką w usta Boga wkłada Pico della Mirandola - małym stwórcą, który posiada moc samokreacji, a życie i świat (materii i idei) są tylko narzędziami owego tworzenia oraz jego przestrzenią ${ }^{60}$. Te dwa typy myślenia stoją wobec siebie w głębokiej opozycji, a z racji fundamentalnego charakteru trudno mówić o możliwości znalezienia jakiejkolwiek wspólnej podstawy, na gruncie której dawałyby

${ }^{58}$ Przedstawiony pogląd, ograniczony jednak tylko do kwestii sztuki, rzeczowo rozwinął Coomaraswamy w artykule A figure of speach, or a figure of thought, dz. cyt., s. 21-51.

${ }^{59} \mathrm{~W}$ tym właśnie miejscu tradycjonaliści podkreślają konieczność unicestwienia - zabicia fałszywej, demonicznej, przywiązanej do subiektywnych dążeń - jaźni (duszy) w celu odrodzenia jaźni autentycznej (ducha). Por. A. K. Coomaraswamy, Who is „Satan” and where is "Hell”, [w:] The essential Ananda K. Coomaraswamy, dz. cyt., s. 25-27.

60 „Nie wyznaczam Ci, Adamie, ani określonej siedziby, ani właściwego oblicza, ani też nie daję Ci żadnej swoistej funkcji, ażebyś jakiejkolwiek siedziby, jakiegokolwiek oblicza lub jakiejkolwiek funkcji zapragniesz, wszystko to posiadał zgodnie ze swoim życzeniem i swoją wolą. Natura wszystkich innych istot została określona i zawiera się w granicach przez nas ustanowionych. Ciebie zaś, nieskrępowanego żadnymi ograniczeniami, oddaję w twoje ręce, abyś swą naturę sam sobie określił, zgodnie z twoją wolą" (Pico della Mirandola, Mowa o godności człowieka, [w:] Wybrane teksy z historii filozofii. Filozofia włoskiego odrodzenia, przeł. A. Nowicki, Warszawa 1967, s. 139). Zgodnie z takim myśleniem filozofowie renesansu próbowali „stworzyć” jedną uniwersalną religię, czemu tradycjonaliści się sprzeciwiają, zalecając praktykowanie religii właściwej danej kulturze. 
się uzgodnić. Są to swoiste paradygmaty, które mogą czasami prowadzić do podobnych działań i przekonań, ale same wzajemnie się wykluczają. Jeśli uznamy istnienie obiektywnych norm, wzorców i zasad, które - jako niezależne od człowieka - winien on rozpoznać i realizować, opowiadamy się za pierwszym, bliskim tradycjonalizmowi rozwiązaniem, na którym opierała się m.in. filozofia Sokratesa, Platona, Arystotelesa i św. Tomasza. Jeśli uznamy, że wszelkie normy są wytworem woli jednostkowej lub wspólnotowej, siłą rzeczy musimy uznać człowieka za ich kreatora oraz opowiedzieć się za sofistami i sceptykami, nawet gdy efektem takich przemyśleń będzie światopogląd konserwatywny. W tym drugim przypadku naturalną konsekwencją uznania człowieka „empirycznego” (tj. pozbawionego wiecznej i niezmiennej istoty skorelowanej na sposób celowy z istotami innych bytów świata) za źródło i miarę „prawd” będzie traktowanie ich jako zmiennych i relatywnie obowiązujących. Między takimi paradygmatami myślenia musi zachodzić permanentny konflikt, a świadome przejście od jednego do drugiego mieć charakter nawrócenia.

\section{Bibliografia}

Coomaraswamy A. K., Who is „Satan" and where is „Hell”, [w:] The essential Ananda K. Coomaraswamy, ed. R. P. Coomaraswamy, Bloomington 2004, s. 23-34.

Coomaraswamy, 2: Selected papers. Metaphysic, ed. R. Lipsey, Princeton 1977.

Coomaraswamy R. P., Ancient beliefs or modern superstitions: the search for authenticity, [w:] The betrayal of tradition. Essays on the spiritual crisis of modernity, ed. H. Oldmeadow, Bloomington 2005, s. 55-73.

Eliade M., Sacrum, mit, historia, przeł. A. Tatarkiewicz, Warszawa 1974.

$\mathrm{Na}$ antypodach modernizmu. Pisma wybrane, red. M. Rostkowski, Biała Podlaska 2014.

Goodrick-Clark N., The western esoteric tradition. A historical introduction, Oxford 2008.

Guénon R., The crisis of the modern world, trans. M. Pallis, A. Osborne, R. C. Nicholson, Hillsdale 2001.

Guénon R., A material civilization, [w:] The betrayal of tradition. Essays on the spiritual crisis of modernity, ed. H. Oldmeadow, Bloomington 2005, s. 18-27.

Guénon R., Not fusion but mutual understanding, [w:] Crossing religious frontiers, ed. H. Oldmeadow, Bloomington 2010, s. 18-27 (Studies in Comparative Religion). 
Guénon R., The great triad, trans. P. Kinsley, Cambridge 1991.

Jagadguru Sri Chandrasekharendra Saraswati Swamigal, On religion, [w:] Crossing religious frontiers, ed. H. Oldmeadow, Bloomington 2010, s. 28-33 (Studies in Comparative Religion).

Mikołaj z Kuzy, On peaceful unity of faith (De pace fidei), [w:] J. Hopkins, Nicolas of Cusa's De pace fidei and Cribatio Alkorani: translation and analysis, Minneapolis 2004, s. 633-676.

Pico della Mirandola, Mowa o godności człowieka, [w:] Wybrane teksy z historii filozofi. Filozofia włoskiego odrodzenia, przeł. A. Nowicki, Warszawa 1967, s. 137-147. Schuon F., Religio perennis, [w:] Crossing religious frontiers, ed. H. Oldmeadow, Bloomington 2010, s. 13-17 (Studies in Comparative Religion).

Schuon F., No activity without truth, [w:] The betrayal of tradition. Essays on the spiritual crisis of modernity, ed. H. Oldmeadow, Bloomington 2005, s. 3-14.

Schuon F., The transcendent unity of religions, Wheaton 2005.

The essential René Guénon. Metaphysic, tradition and the crisis of modernity, ed. J. Herlihy, Bloomington 2009.

\section{Streszczenie}

Przedmiotem niniejszej pracy jest krytyka nowożytnych form chrześcijaństwa zachodniego sformułowana przez głównych przedstawicieli tradycjonalizmu integralnego. Celem pracy jest wskazanie najważniejszych zarzutów ze szczególnym uwzględnieniem ich metodologicznego tła. Za podstawową przyczynę degeneracji nowożytnej kultury i religii uznano renesansowy humanizm tożsamy $\mathrm{z}$ antropocentryzmem i indywidualizmem. Skutkiem takiej zmiany perspektywy był upadek tradycyjnej metafizyki pojmującej człowieka w kontekście hierarchicznie uporządkowanego świata, będącego przejawem boskiego ładu, którego człowiek był częścią. W kontekście religijnym efektem przeniesienia akcentów z wszechświata na człowieka jest sentymentalizm, moralizm i synkretyzm religijny, które swój najpełniejszy wyraz znalazły w protestantyzmie.

\section{Słowa kluczowe}

tradycjonalizm integralny, filozofia wieczysta, krytyka nowoczesności, antropocentryzm 


\section{Summary}

\section{Criticism of modern forms of Christianity from the integral traditionalist's point of view}

The purpouse of this paper is to examine main objection against modern form of western christianity formulated by representatives of Traditionalist School (R. Guénon, F. Schuon, A. K. Coomaraswamy). According to traditionalist's point of view degeneration of contemporary culture was caused by metaphysical shift toward humanism, indyvidualism and anthropocentrism, which began XIV century and gradually destroyed whole hierarchical and theocentrical culture. In case of religion this revolution led to sentimentalism, moralism, and religious syncretism. These attitudes realised by Reformation spoiled not only modern theology but whole religious world view.

\section{Keywords}

traditionalism, humanism, perennial philosophy 